Dariusz Kuźmina

Warszawa

\title{
Pierwszy opis powstania zakonu jezuitów w języku polskim
}

Towarzystwo Jezusowe zostało powołane do życia w roku 1540 bullą Regimini militantis Ecclesiae w Rzymie przez papieża Pawła III. Założyciel wspólnoty zakonnej Inigo Lopez de Loyola, człowiek wielkiej wiary, nie przewidział tak szybkiego i niezwykle imponującego rozwoju swojego dzieła. Przed wydaniem decyzji Stolicy Apostolskiej był skłonny zaakceptować, iż jego współbracia nie przekroczą w przyszłości liczby 60 zakonników. Do końca XVI w. Towarzystwo Jezusowe liczyło około tysiąca członków.

Po wspaniałych początkach we Włoszech, a zwłaszcza udanej prezentacji swoich możliwości intelektualnych na Soborze w Trydencie, jezuici zostali zaproszeni do Polski przez kardynała Stanisława Hozjusza i osiedlili się w Braniewie.

Poszukując pierwszego opisu historii powstania jezuitów w języku polskim natrafiamy na liczne trudności. W literaturze przedmiotu, zarówno w pierwszej całościowej historii Towarzystwa Jezusowego autorstwa Stanisława Załęskiego $\mathrm{SJ}^{1}$, jak również w obszernym artykule Bronisława Natońskiego $\mathrm{SJ}^{2}$, poświęconym pierwszym latom funkcjonowania zakonu w Polsce, nie odnajdujemy wzmianki o wcześniejszych pracach o charakterze historycznym. Załęski w swojej bibliografii i wprowadzeniu do pierwszego tomu nie odnotowal żadnej pracy wcześniejszej w języku łacińskim ani polskim, zaprezentował jedynie wydania źródłowe ${ }^{3}$. W języku łacińskim znaną pozycją w Rzeczypospolitej było dzieło napisane w języku łacińskim przez Nicolausa Lanciciusa (dalej Mikołaj Łęczycki), Vita Beati P. Ignatii Loiolae Societatis Iesu Fundatoris, wydane w Krakowie w roku 1622. Pod względem objętości książka raczej bardzo skromna, w formacie kieszonkowym, zawierająca podstawowe dane o założycielach jezuitów, wydawana była kilkakrotnie w XVII wieku ${ }^{4}$. Autor tej książki, po przyjęciu święceń kapłańskich w Rzymie w roku 1601, współpracował w latach 1601-1605 z Mi-

\footnotetext{
${ }^{1}$ S. Załęski, Jezuici w Polsce, t. 1-5, Lwów-Kraków 1900-1906.

${ }^{2}$ B. Natoński, Początki i rozwój Towarzystwa Jezusowego w Polsce 1564-1580, w: J. Brodrick, Powstanie i rozwój Towarzystwa Jezusowego, t. 1, Kraków 1969, s. 414-476.

${ }^{3}$ S. Załęski, dz. cyt., s. V-XVI.

${ }^{4}$ K. Estreicher, Bibliografia polska, t. 21, s. 40-41.
} 
kołajem Orlandinim, który badał źródła i opisywał historię zakonu ${ }^{5}$. Mikołaj Łęczycki jest niewątpliwie pierwszym Polakiem, o którym można powiedzieć, iż analizował dzieje wspólnoty jezuickiej. Uchodzi więc za prekursora współczesnych historyków zakonu w Polsce, co sugerował Kazimierz Kojałowicz w XVII wieku, opisując postępy prac Łęczyckiego w archiwum w Rzymie ${ }^{6}$. Poza badaniem historii zakonu zajmował sie także tworzeniem dzieł o charakterze ascetycznym w duchowości jezuickiej; przykładem jest tłumaczenie: Zacność stanu braci do posług domowych Societatis Jesu na pogłębionej pokorze, od św. Ojca naszego Ignacego Loyola fundatora Societatis Jesu ugruntowana, wydane we Lwowie w roku 1730.

Książki Łęczyckiego były wznawiane także w XIX wieku, ale wydawano je często $\mathrm{w}$ języku łacińskim. $\mathrm{W}$ trakcie poszukiwań pierwszych opracowań historii, czy chociażby zarysu początków zakonu jezuitów w języku polskim, analizowałem wszystkie publikacje jezuity Jakuba Wujka. W jego Dialysis. To jest, Rozwiqzanie albo rozebranie Asserciy Pana Jakóba Niemojewskiego z Dowodami iego naprzeciw Jezuitom Poznańskim wydanych: Napisane przez Professory Collegium Poznańskiego Societatis Jesu został zawarty pierwszy opis powstania zakonu w języku polskim. Praca ukazała się w drukarni Jana Wolraba w lipcu 1580 r. w formacie $8^{\circ}$, stron 233 odręcznie ponumerowanych. Na końcu książki umieszczono spis treści i wykaz pomyłek zecerskich, jakie powstały w druku. Jest ich stosunkowo niewiele jak na owe czasy. Na marginesach zaznaczone glosy dołączone do tekstu. Publikacja ta należy do dzieł o charakterze apologetyczno-dogmatycznym. Autorstwo Jakuba Wujka nie ulega wątpliwości, zaznaczono to we wprowadzeniu. Natomiast zaakcentowanie w tytule dzieła, zostało napisane przez profesorów Towarzystwa, wzmacniało wagę wykładu podejmowanego $\mathrm{w}$ pracy oraz było uzasadnione wzajemnymi relacjami jezuitów z Jakubem Niemojewskim, który był jednym $z$ głównych adwersarzy jezuitów w Poznaniu. Dzieło powstało, gdy Wujek pełnił obowiązki rektora wspólnoty w stolicy Wielkopolski, a wyszło drukiem gdy udał się na pierwszą misję do Siedmiogrodu.

Dzieło dedykowane zostało biskupowi poznańskiemu Łukaszowi Kościeleckiemu; dowodzi tego dodatkowo jego imprimatur oraz herb. Wprowadzenie uzasadnia powód napisania tej publikacji. Zgodnie $z$ nim, stanowi ona odpowiedź na pracę Jakuba Niemojewskiego Diatryba ..., wydaną w roku 1579. Wujek wskazuje również, że należało napisać odpowiedź, ponieważ nie doszło do bezpośredniego spotkania $z$ autorem i publicznej dysputy. Jezuici proponowali, aby odbyć ją w języku łacińskim, Niemojewski natomiast chciał, by była prowadzona po polskư ${ }^{7}$. Dialysis została podzielona na trzynaście rozdziałów. Wujek prezentuje fragmenty $z$ pracy adwersarza, a następnie przytacza swój komen-

\footnotetext{
${ }^{5}$ B. Natoński, Mikołaj Łęczycki, w: PSB, t. XVIII, Kraków 173, s. 347-350; L. Grzebień, Encyklopedia wiedzy o jezuitach na ziemiach Polski i Litwy, Kraków 2004, s. 388.

${ }^{6}$ K. W. Kojałowicz, Vita venerabilis patris Nicolai Lancici e Societate Jesu, Praga 1690, s. 33-40.

${ }^{7}$ J. Wujek, Dialysis, Poznań 1580, k. 9.
} 
tarz. Cytaty, bez zaznaczania stron, są wyróżnione petitem. W pierwszym rozdziale opisane są wydarzenia, które doprowadziły do napisania tego dzieła i sposób, w jaki Niemojewski starał się doprowadzić do publicznej dyskusji. Uwzględnił także autor krótki rys historyczny sprowadzenia jezuitów do Poznania oraz wyjaśnił znaczenie i pochodzenie nazwy swego zakonu ${ }^{8}$. Głównym problemem podnoszonym w trzech pierwszych rozdziałach jest kwestia języka, w jakim należy prowadzić dysputy. Jezuici, powołując się na naukę św. Pawła i tradycję, uznawali, że tylko po łacinie, czego wymaga precyzja określeń teologicznych. $\mathrm{W}$ trzecim rozdziale autor ponownie odwołał się do rozmowy odbytej przez Niemojewskiego $z$ jezuitą Franciszkiem Toletusem w Warszawie w roku 1572. Ten wątek, jak wspomniano wyżej, znajdował swoje odniesienie we wszystkich publikacjach poznańskich jezuitów. Ocena tego spotkania jest bardzo niekorzystna: Jakub Wujek uznał, że przygotowanie adwersarza $z$ Poznania było słabe, niekorzystne też odniósł wrażenie w związku z brakiem jego biegłości w znajomości pism Ojców Kościoła9 . Jako dowód wskazuje pozytywną ocenę jaką współbrat zakonny otrzymał od organizatora tej dysputy nuncjusza Jana Franciszka Comenndoniego oraz Jana Chodkiewicza „dla którego ta rozmowa była, wyznał przed wszystkimi, że przez nie, był powszechnej wierze tym więcej umocniony”"10.

W dalszej części dzieła Wujek przedstawia dowody o charakterze teologicznym, którymi zbija tezy Niemojewskiego. Autor staje na stanowisku pełnej obecności Jezusa Chrystusa w Najświętszym Sakramencie. Łączy Jego całkowitą obecność $z$ Męką, w której był obecny całą swoją osobą - zarówno boską, jak ludzką naturą. Pod względem chronologicznym jest to druga praca podejmująca zagadnienia sakramentalne.

Pewną ciekawostką jest powracanie do Komunii Świętej pod jedną postacią, z użyciem argumentów dotyczących zwyczajów sięgających pierwszych wieków chrześcijaństwa. Cały dowód VII w rozdziale $O$ ofierze Mszy świętej został poświęcony udzielaniu sakramentu Eucharystii. Wujek, powołując się na tradycję i Pismo Święte, nie widzi potrzeby udzielania Komunii Świętej pod dwiema postaciami. Chrystus, jego zdaniem, umarł tylko raz; ustanawiając sakrament, udzielił go pod dwoma postaciami tylko swoim apostołom, a ci przekazali to kapłanom. W dalszej działalności czynili to tylko pod postacią chleba ${ }^{11}$.

W argumentacji tej widać pewną niekonsekwencję w ujmowaniu postanowień Soboru w Trydencie, który zezwalał na udzielanie komunii pod postacią chleba i wina. Jakub Wujek, zawsze tak dbający o propagowanie ustaleń ojców soborowych, tak dalece wszedł w polemikę, iż postanowił łagodzić dogmaty Kościoła na rzecz pełniejszej różnicy w pojmowaniu Mszy świętej pomiędzy protestantami a katolikami.

Najbardziej interesujący, $z$ racji historycznych i bibliologicznych, jest rozdział

\footnotetext{
${ }^{8}$ Tamże, k. 13.

${ }^{9}$ Tamże, k. 28-30.

${ }^{10}$ Tamże, k. 29.

${ }^{11}$ Tamże, k. 176-191.
} 
czwarty, zawarty na kartach od 30 do 42, w którym znajduje się krótka historia Towarzystwa Jezusowego, podzielona na trzy części: 1) O początkach zakonu Clericorum Societatis Jesu, to jest księżej pod imieniem Jezusa Pana zgromadzonej ${ }^{12}$; 2) O poczatkach Societatis Jesu ex Surio; 3) O przezwisku Societatis Jesu.

Na podstawie literatury przedmiotu należy wnioskować, że były to pierwsze próby przedstawienia dziejów zakonu w języku polskim. Tekst Jakuba Wujka w drugiej części jest wzorowany na pracy Wawrzyńca Suriusa (1523-1578) pisarza katolickiego, członka wspólnoty kartuskiej, który wydał w Kolonii w 1566 r. Commentario brevis rerum in orbe gestarum. Książka ta to prezentacja najważniejszych wydarzeń w Europie pod kątem historii Kościoła. Warto zaznaczyć, iż Surius przyczynił się do namówienia Piotra Kanizego, gdy ten przebywał w Kolonii, by poświęcił się studiom teologicznym i został duchownym ${ }^{13}$. Drugie dzieło, na które powołuje się Wujek, to Librum primum Jakuba Payuae Lusitani. Niestety nie znamy tego druku, ale przydomek autora wskazuje na pochodzenie portugalskie, co w tradycji pierwszych opisów zakonu jest dość charakterystyczne. Znane spory prowadzone przez jezuitów $z$ Półwyspu Iberyjskiego w sprawie druku Franciszka Sacchiniego Historia, wydanego w 1614 roku w Antwerpii, sugerują, iż pierwsze zarysy historii zakonu ${ }^{14}$ mogły powstawać na tamtych ziemiach.

Wujek, jak wynika $z$ porównania fragmentów odnoszących się do opisu powstania jezuitów, które zostały opublikowane u Suriusa, możemy stwierdzić, iż dokonał tłumaczenia, które skompilował na podstawie znajomości całej pracy kartuza. Podstawowy fragment, który pozwala potwierdzić tezę o tłumaczeniu, znajduje się na stronach od 402 do 411.

Autor opisu początków jezuitów wskazuje za tekstem Biblii, iż Bóg powoływał wybitnych ludzi do specjalnych dzieł. Wymienia $z$ przeszłości świętych: Antoniego, Bazylego, Augustyna, Benedykta, Franciszka, Dominika. Jako przyczynę bezpośrednią powołania przez Ignacego de Loyola zakonu wskazuje na działalność Marcina Lutra. Umiejscawia tym samym swojego założyciela w gronie świętych, chociaż jeszcze nim nie był oraz mówi pośrednio, iż Towarzystwo powstało w celu podjęcia walki $z$ reformacją, która pojawiła się w XVI wieku. Dalszy tekst odbiega od tej interpretacji, ponieważ zakon jest prezentowany jako siła skierowana do działań o charakterze misyjnym, a nie kontrreformatorskim. Wnioskować $z$ tego możemy, że już w czasach pierwszych jezuitów idea założyciela, czyli podróż do ziemi muzułmańskiej i nawracanie niewiernych, walczyła $z$ najważniejszą duchową potrzebą ówczesnej Europy, czyli jej reewangelizacją.

Po wprowadzeniu Wujek przeszedł do zasadniczej prezentacji historii zatytułowanej O początkach Societatis Jesu ex Surio ${ }^{15}$. Rozpoczą ją wymienieniem

\footnotetext{
${ }^{12}$ J. Wujek, Dialysis, k. 30.

${ }^{13}$ M. Bednarz, Pisma wybrane, t. 2, Kraków 1969, s. 596.

${ }^{14}$ Zob. J. Brodrick, Powstanie i rozwój Towarzystwa Jezusowego, Kraków 1569, s. 402-413.

${ }^{15}$ J. Wujek, Dialysis, k. 31.
} 
nazwy bulli, którą Paweł III dał oficjalny początek działalności zakonu, następnie opisał moment nawrócenia Ignacego de Loyola, skupiając się na jego walce w wojnie pomiędzy Hiszpanią a Francją. Ciekawym, charakterystycznym dla języka polskiego i tytulatury, jest nazwanie Ignacego - hetmanem w czasie działań wojennych. Nawrócenie i lektura żywotów świętych, które nie zostały wymienione $z$ tytułów zaprowadziły Loyolę do Manrezy, gdzie rozpoczął swoje życie duchowe. Studia we Francji i Hiszpanii, a przede wszystkim powstanie grupy siedmiu towarzyszy, których autor nie wymienia $z$ nazwiska, a która rozpoczęła działalność we Włoszech i nosiła się z zamiarem wyjechania do Ziemi Świętej w celu nawracania pogan. Wujek podkreślił znaczenie kardynała Gaspara Contariniego, który wstawił się za Loyolą i jego towarzyszami u papieża Pawła III i przyczynił się do zatwierdzenia zakonu. W tekście odnajdujemy także potwierdzenie ponownego uznania zakonu w 1543 ze zmieniona formuła co do jego liczebności. Doskonałym posumowaniem pierwszej części zarysu historii zakonu są słowa: „Teć są początki tego Zebrania. Którego jaki potem postępek był i jako się za mały czas rozmnożył, i po wszystkim świecie aż do ostatecznych Indów, Murzynów i Antypodów." "16

W drugiej części opisu początku swojego zakonu Wujek podkreśla zasadnicze zadania, które postawił przed zakonem Sobór w Trydencie. Zaznaczył, że w przeciwieństwie do ewangelików czyli protestantów, którzy bieżą, nie będąc od nikogo posłani i sierpy swe niewstydliwie w cudze żniwo wtrącają ${ }^{17}$, jezuici wypełniają zadania powierzone przez papieża i generała. Występuje przeciwko zarzutom, iż kolegium utworzone w Rzymie kształci obywateli $z$ obszaru Niemiec nie na członków swojego zakonu, lecz dla powrotu ich do kraju i samodzielnej walki $z$ reformacją. Wymienił przy kwestii niemieckiej kardynała Jana Morone, który współpracował $z$ Ignacym de Loyola w założeniu kolegium w Wiecznym Mieście. Wspomniany jest także cesarz Fryderyk I, jako obrońca Stolicy Apostolskiej.

W dalszej części zostały bardzo krótko opisane działania misyjne Franciszka Ksawerego i Gonzalo da Silveira, którzy pracowali na misjach w Indiach, Japonii i Afryce. Kończy opis początków historii zakonu wskazaniem, iz autor, z którego czerpał, czyli Surius, w dalszej części swojej pracy opisał kolejne doświadczenia pierwszych jezuitów oraz inne wydarzenia $Z$ życia szesnastowiecznej Europy.

Ostatnia część, zawierająca informacje o pierwszych członkach zakonu przedstawia tłumaczenie nazwy wspólnoty. Wujek wraca do wątku polemiki i wskazuje, $\mathrm{i} z \dot{z}$ istnieje potrzeba wyjaśnienia popularnego określenia jego zakonu - jezuici. Nazwa Towarzystwo Jezusowe została wykreowana nie ze względu na pychę jego założyciela i pierwszych współbraci Loyoli, ale $z$ potrzeby całkowitego służenia Jezusowi. Pierwszy człon nazwy związany jest $z$ popularnymi we Włoszech określeniami dla bractw - Compania lub Societas. Wujek wymienia

\footnotetext{
${ }^{16}$ Tamże, k. 35.

${ }^{17}$ Tamże, k. 35.
} 
kilka przykładów takich wspólnot. Złośliwe określenie - jezuici - jak uznaje Wujek - „tegośmy nazwiska nie my wymyślili, ale już tak zwyczaj u ludzi otrzymal. Quem penes arbitrium est, vis norma loquendi" ${ }^{18}$ (wyrok jest w mocy, którego siła wypowiedzenia jest reguła). Dla polskich jezuitów nazwa ich wspólnoty stanowiła także pewien problem. Zajęła się tym m.in. kongregacja zwołana w styczniu 1576 r. do Boszewa, na której ustalono polską nazwę zakonu - Towarzystwo Jezusowe ${ }^{19}$.

W tekście odnaleźć można kilka błędów, wynikających $z$ naśladownictwa Suriusa przez Wujka, a odnoszących się do określenia daty nawrócenia założyciela jezuitów oraz jego podróży po Europie w latach trzydziestych XVI w. Autor wskazał na datę nawrócenia się Ignacego (poprzez podanie jego wieku - 26 lat Loyola urodził się w 1491 r.) jako rok 1517, co w oczywisty sposób miałoby wskazywać na początek działalności Marcina Lutra i nawrócenie późniejszego pierwszego generała Towarzystwa Jezusowego. Takie zabiegi podkreślają w pierwszym zarysie historii zakonu, iż wspólnota stawia sobie za cel walkę $z$ ruchem reformacyjnym i została do tego powołana.

Praca Jakuba Wujka Dialysis, przyczyniła się do upowszechnienia w języku narodowym podstawowych informacji o wspólnocie jezuitów w Rzeczypospolitej. Historia została umieszczona $\mathrm{w}$ dziele $\mathrm{z}$ racji swego przeznaczenia: miało odpierać ataki ze strony różnowierców. Autor wykorzystuje więc wiedzę o charakterze historycznym do wzmocnienia prezentowanych przez siebie i współbraci prawd dogmatycznych. Podkreśla silne związki zakonu z papieżem przez co stara się forsować tezę, tak często wykorzystywaną w literaturze apologetycznej, o ciągłości i prawdziwości wykładania nauki o Bogu ze względu na łączność ze Stolica Apostolską. Nowym wyznaniom reformowanym zarzucano odejście od korzeni, czyli pierwszego Kościoła, który powstał pod rządami św. Piotra.

Tekst Wujka nie był powielany w innych publikacjach, wynikało to - jak można przypuszczać $-z$ faktu jego umiejscowienia $\mathrm{w}$ dziele typowo apologetycznym, które znajdowało odbiorców w dość wąskim kręgu. Po uciszeniu sporów pomiędzy jezuitami a Niemojewskim nie istniała dalsza konieczność ponownego powracania do tej książki, co powodowało koniec jej oddziaływania. Język polski w XVI w. także nie należał do szczególnie uprzywilejowanych wśród pisarzy jezuickich, nadal dominowało publikowanie dzieł po łacinie.

\footnotetext{
${ }^{18}$ Tamże, 42.

${ }^{19}$ Archiwum Archidiecezji War-szawskiej, sygn. 440, s. 24r-24v, Acta et Historia Collegii Posnanniensis Societatis Iesu 1574-1606.
} 